\title{
Allelopathy of Medicinal Plants: Current Status and Future Prospects in Weed Management
}

\author{
A. K. M. Mominul Islam ${ }^{1,2}$, Sabina Yeasmin'2, Jamal Ragheb Said Qasem³, \\ Abdul Shukor Juraimi ${ }^{4}$, Md. Parvez Anwar ${ }^{1,2}$
}

${ }^{1}$ Weed Management Laboratory, Department of Agronomy, Bangladesh Agricultural University, Mymensingh, Bangladesh

${ }^{2}$ Department of Agronomy, Bangladesh Agricultural University, Mymensingh, Bangladesh

${ }^{3}$ Department of Plant Protection, Faculty of Agriculture, University of Jordan, Amman, Jordan

${ }^{4}$ Department of Crop Science, University of Putra Malaysia, Serdang, Malaysia

Email: *akmmominulislam@bau.edu.bd

How to cite this paper: Islam, A.K.M.M., Yeasmin, S., Qasem, J.R.S., Juraimi, A.S. and Anwar, Md.P. (2018) Allelopathy of Medicinal Plants: Current Status and Future Prospects in Weed Management. Agricultural Sciences, 9, 1569-1588. https://doi.org/10.4236/as.2018.912110

Received: November 12, 2018 Accepted: December 11, 2018 Published: December 14, 2018

Copyright $\odot 2018$ by authors and Scientific Research Publishing Inc. This work is licensed under the Creative Commons Attribution International License (CC BY 4.0).

http://creativecommons.org/licenses/by/4.0/

\begin{abstract}
An attempt has been made in this article to accumulate and elucidate the literatures about the allelopathic potentiality of medicinal plants, and its role on the development of bio-herbicides for eco-friendly weed management strategies to conserve bio-diversity and ecological balance. This review paper has been prepared by comprehensive studies of various published research articles, books and proceedings available in the world literature. The farmers of different countries use several weed management techniques in order to minimize the deleterious effect of weeds. Among them most commonly used practice is application of herbicides due to its high efficacy and cost effectiveness, less time-consuming nature, flexibility and easy accessibility, and more rapid out return. Although use of synthetic herbicides in the crop fields has increased the crop production as well as the productivity by reducing the weed infestation, over time it causes a number of environmental hazards. Hence, to avoid these detrimental effects of synthetic herbicide, a lot of efforts have been dedicated by the researchers to search the novel natural plant products mainly allelochemicals and try to apply them as a tool for the development of bio-degradable natural herbicides. This paper intended to reflect the current state of allelopathic medicinal plants and their potentiality to develop eco-friendly and natural product-based herbicides for sustainable agriculture, and to invite further debate on this issue.
\end{abstract}

\section{Keywords}

Allelochemicals, Medicinal Plants, Natural Products, Bio-Herbicides, Sustainable Weed Management 


\section{Introduction}

Among the deleterious pests of crops, weeds rank the first as it causes severe loss of crop yields, which is even more than the combined losses caused by plant pathogens and insect pests worldwide. Around 33\% - 53\% crop produce is damaged if weeds are not controlled in the crop fields [1] [2] [3]. Even after adopting conventional weed control techniques, $13 \%-30 \%$ of crop produce is lost from the farmers' fields [1] [4] [5].

Since the inception of first commercial herbicide in 1940s farmers are using thousand tons of herbicide every year to control weeds across the globe. Excessive use of synthetic herbicide lead to a tremendous environmental hazards [6] [7] [8] including development of herbicide resistant weed biotypes [9]. Therefore, for the sake of pollution free earth ecosystem and sustainability in crop productivity, conventional agriculture has to be improved by limiting the use of synthetic agrochemical including chemical herbicides. Researchers around the world are therefore now searching for new natural plant products to develop biodegradable and cost effective herbicides for sustainable weed management.

The impact of plants upon neighboring plants or their associated micro-flora and/or macro-flora by the production of allelochemicals is known as allelopathy [10]. Allelopathic substances are released into the surrounding environment (atmosphere or rhizosphere) through a number of ways [11], and upon release may suppress the germination, growth and establishment of neighboring plants, even the donor species itself either directly by affecting their physiological properties [12] [13], or indirectly by modifying the rhizosphere soil properties through influencing the microbial biomass carbon and microbial community [14] [15] [16]. Thus, allelopathic substances play a vital role in regulating the structure of plant communities [17], and thus could be used as lead for biodegradable herbicide production [18] [19].

Medicinal plants have a great history as a source of potential therapeutic agents, which have been incorporated into modern medicine [20] [21] [22]. There are about 422,000 flowering plant species in the world, out of which 52,885 plant species are considered medicinal plants [23]. Of these, the biological activity of only about $6 \%$ has been screened, with $15 \%$ having been phytochemically evaluated [24] [25] [26]. On the other hand, there are about 400,000 secondary metabolites in plants [27], of which only a few have been examined for their biological or herbicidal activities [28]. The biological or herbicidal potentialities of rest of the compounds are still unexplored. The present study reviews the present status and future prospects of allelopathic medicinal plants in controlling major crop weeds for sustainable agricultural production.

\section{Allelopathic Activities of Medicinal Plants}

Medicinal plants are considered as an important source of secondary metabolites that usually have a number of biological functions. It has been reported that medicinal plants species possess strong allelopathic potential [11] [29] [30] [31]. 
Many researchers around the world are now showing their keen interest on medicinal plants for searching new natural plant products, [32]-[37]. Islam and Kato-Noguchi [38] stated two reasons for this increasing interest: 1) the easier screening process of phytotoxic plants from medicinal plants and 2) the possibility to have more bioactive compounds in medicinal plants than other plants. Fujii et al. [39] carried out the first comprehensive studies of allelopathic medicinal plants. They evaluated 387 Japanese medicinal plants and observed that a considerable number of those have growth inhibitory potential [39] [40] [41]. Azizi et al. [42] examined 56 aromatic medicinal plants of 22 families from Iran for their allelopathic potential and found 51 species inhibited the seedling growth of lettuce. Gilani et al. [43] also evaluated 81 medicinal plant species of Pakistan and reported 78 as allelopathic potential inhibiting the root growth of lettuce. Mardani et al. [44] recently evaluated the allelopathic potential of 83 Iranian medicinal plants and observed more than $80 \%$ root growth suppression of lettuce by Peganum harmala, Berberis vulgaris, Artemisia aucheri and Ferulago angulata. Amini et al. [45] investigated the allelopathic potential of 68 medicinal and wild plant species belong to 19 plant families grown in Iran. Among the examined plant species, stigma and style of Crocus sativus, leaves of Artemisia kopetdaghensis, Mentha piperita, Zhumeria majdae, Frulago subvelutina, flowers bud of Eugenia caryophyllata, flower of Perovskia abrotanoides, fruits of Melia azedarach and Ruta graveolen had the strongest inhibitory effects on lettuce seedling growth. Islam et al. [46] on the other hand, examined the allelopathic properties of 55 tropical medicinal plant species of Bangladesh representing 32 different families. All the medicinal plant species except Garcinia mangostana (Clusiaceae) and Schleichera oleosa (Sapindaceae) showed allelopathic potential. Moreover, among the plant species, Citrus aurantifolia (Rotaceae), Moringa oleifera (Moringaceae), Annona muricata (Annonaceae), Aegle marmelos (Rutaceae), Cinnamomum tamala (Lauraceae) and Azadirachta indica (Meliaceae) completely (100\%) inhibited the growth of Raphanus. sativus. From two different studies Piyatida and Kato-Noguchi [47] and Suwitchayanon et al. [48] evaluated 25 medicinal plants of Thailand and reported that the extract obtained from Cymbopogon nardus, Piper retrofractum, Piper sarmentosum, Rhinacanthus nasutus and Tinospora tuberculata possessed the highest allelopathic potential against the seedling growth of lettuce. Qasem [31] examined 30 medicinal plant species of Jordan for their herbicidal activities against Amaranthus retroflexus and Chenopodium murale in laboratory and glasshouse conditions. In laboratory study, the aqueous extracts of Alhagi maurorum, Capparis spinosa, Citrullus colocynthis, Lavandula officinalis, Origanum syriacum, Rhus coriaria. Ricinus communis, Rosmarinus officinalis and Teucrium polium either prevented seed germination or reduced seedling growth. Whereas, in glasshouse experiment addition of $2 \mathrm{~g} \mathrm{~kg}^{-1}$ dried shoot material of $L$. officinalis or $R$. officinalis to the potted soil mixture was highly toxic to weed germination and growth, and addition of $16 \mathrm{~g} \mathrm{~kg}^{-1}$ of $C$. spinosa, R. coriaria, and T. polium severely reduced 
weed growth. Many other researchers for example, Khanh et al. [49], Azizi and Fujii [32], Khan et al. [50], Anjum et al. [51], Laosinwattana et al. [52], Islam and Kato-noguchi [53] Islam and Kato-Noguchi [54], Khan et al. [55], Islam and Kato-Noguchi [56], Islam et al. [57], Islam and Kato-Noguchi [58], Itani et al. [59], Baličević et al. [60], Qasem [61] and Algandaby and El-Darier [62] worked with several medicinal plants species and observed that most of the species possessed strong allelopathic properties and inhibited the growth of test plant species with different inhibition values.

\section{Scope of Using Natural Plant Products in Weed Management}

Since the inception of agriculture, different types of natural plant products have been used to control pests mainly insect and disease organisms. More evidences have been found in the world literature about the use of natural product as fungicides, insecticides, and other pesticides than as herbicides [63]. Although natural product based herbicides for weed control strategies have not yet been as successful as like other pesticides, however, there have some notable success stories [64]. Nowadays, the use of allelopathic medicinal plants has been suggested as a viable option for alternative weed management in sustainable agriculture [65] [66] [67]. Yang and Tang [68], described two ways of plant utilization for weed management: 1) the active compounds are isolated, identified and chemically synthesized; if possible, these compounds or their active analogs are produced by the chemical industry, 2) plant tissue or a crude product of the plant, such as aqueous or organic extract is used directly. The last one is more labor intensive, but is often economically and ecologically sounds, and does not require sophisticated technology, and thus is suitable for the farmers in developing countries and also for organic farming.

Duke et al. [19] proposed three approaches to select the sources of natural products for the discovery of potential herbicides: 1 ) to obtain pure compounds from other scientists, 2) to obtain biological material that has not previously been studied, and 3) to use ethnobiological and/or chemical ecology clues. However, ethnobotanical knowledge showed better performance only in case of pharmaceutical, rodenticide and insecticide discovery, but not for phytotoxins. In this backdrop chemical ecology provides some important clues. They suggested two chemical ecology approaches to identify phytotoxic plants: a) allelopathic activity has been the most common approach; an example of this strategy is the discovery of sorgoleone from allelopathic sorghum species [69] [70], b) the second approach is to examine compounds on that plant species have sequestered to avoid autotoxicity, for examples, artemisinin and hypericin [71].

\section{Prospects and Status of Allelopathic Plants in Weed Management}

The allelopathic plants have been suggested as a viable option for alternative weed management under sustainable agriculture [65] [66] [67] [72] [73]. These 
plants could be exploited in weed management through a number of processes. For example, use them as cover/smother crops [74] [75] [76], rotational/companion crops [77], application of their extracts [78] [79] [80] [81], incorporation of their residues or their different parts as mulch [82] [83] [84], application of allelopathic substances as natural herbicides [82] [85], use of allelopathic plant extracts with lower herbicide doses [79] [86] [87] or development of allelopathic crop cultivars through breeding program [88] [89].

Substantial number of reports has been documented in the literature about the successful use of allelopathic plants, their extracts/residues, or the allelopathic substances into the crop fields as a substitute of synthetic herbicides to control weeds. Mushtaq et al. [90] opined that herbicide use could be reduced by $75 \%$ through integration with sorghum and sunflower extracts without compromising yield and net benefits for cost-effective and eco-friendly control of wild oat and canary grass in wheat. Xuan et al. [91] found that alfalfa pellets at $1-2 \mathrm{t} \cdot \mathrm{ha}^{-1}$ completely inhibited the emergence of Dopatrium junceum, Lindernia pyxidaria and Elatine triandra, and also reduced the number and dry weight of emerged Echinochloa oryzicola. Hong et al. [92] worked with ten allelopathic higher plants (Ageratum conyzoides, Bidens pilosa, Blechnum orientale, Eupatorium canabium, Euphorbia hirta, Galactia pendula, Leucana glauca, Melia azedarach, Morus alba, and Tephrosia candida) and revealed that all the species at $2 \mathrm{t} \cdot \mathrm{ha}^{-1}$ significantly reduced paddy weed growth and promoted the rice growth and yield. Among those species, B. pilosa and T. candida showed the highest potential to reduce more than $80 \%$ weeds and to increase rice yields by up to $20 \%$. Many other examples are found in the literatures that are potential to control weeds [49] [89]. From another field experiment in Thailand, Laosinwattana et al. [52] reported that the powders of the Aglaia odorata leaves inhibited the emergence and growth of Digitaria adscendens, Trianthema portulacastrum, and Amaranthus gracilis at a dosage of $1 \mathrm{t} \cdot \mathrm{ha}^{-1}$. A bioherbicide PORGANIC ${ }^{\mathrm{TM}}$ was then developed from the leaf extracts of this plants, which had significant inhibitory effects on Echinochloa crusgalli and Sphenoclea zeylanica at a dosage of $10 \mathrm{~kg} \cdot \mathrm{ha}^{-1}[93]$.

Xuan et al. [94] demonstrated that allelopathic plant extracts performed better than synthetic herbicides to control weeds. They observed that Japanese alfalfa variety (Rasen) inhibited $80 \%$ total weed biomass and promoted $81 \%$ rice yield when compared with the control (without any weed and fertilizer management). In contrast, herbicide treatment suppressed $75 \%$ paddy weeds but increased rice yield by only $10 \%$, and those for hand weeding were about $70 \%$ and $25 \%$, respectively.

As stated earlier, an increasing number of weeds are now gaining resistant to several synthetic herbicides. Therefore, it is much difficult to control them through synthetic herbicides. Allelopathic plants showed promising results in controlling those weeds. In Japan, Rotala indica showed strong resistance to some common herbicides. Application of alfalfa and rice byproducts at the rate 
of $1-2 \mathrm{t} \cdot \mathrm{ha}^{-1}$ could completely inhibit the emergence of this noxious weed, and A. conyzoides, B. pilosa, G. pendula, L. glauca and Piper methysticum inhibited significantly $R$. indica at the same dose [94].

Xuan et al. [94] also reported that $70 \%-80 \%$ weed reduction could be attained through the incorporation of $1-2 \mathrm{t} \cdot \mathrm{ha}^{-1}$ of strong allelopathic plants. Although the inhibitory activity of allelopathic plant biomass is dose-dependent, they suggested not exceeding the limit above $2 \mathrm{t} \cdot \mathrm{ha}^{-1}$. Otherwise, it will be laborious and costly. The most important obstacle to use plant biomass is that it needs water for decomposition. Therefore, it is very difficult to apply plant biomass in highland areas where water crisis exists. To overcome this problem many researchers currently focuses on allelopathic substances rather than the plant itself. They stated that if allelopathic substances with stronger activity on weeds are deployed as a tool for new natural herbicides development, the burden from plant residue application could be minimized.

Sorgoleone, an isolated allelochemicals exudate from Sorghum root hair, has been characterized as a potent bio-herbicide. It is phytotoxic to broadleaf and grass weeds at concentrations lower than $10 \mu \mathrm{M}$ [95] [96]. Post-emergent foliar application of Sorgoleone, at a similar concentration to labelled field rates of Atrazine $\left(0.6 \mathrm{~kg}\right.$ a.i. ha $\left.{ }^{-1}\right)$, inhibited growth of most of the small-seeded broadleaf weeds [97]. Pre-emergence soil applications were also toxic to certain small-seeded weed species [98]. The allelochemicals of tomato e.g., tomatine and tomatidine also reduce the growth of weeds, pathogenic fungi at a satisfactory level [99].

Several types of allelochemicals for examples, phenolics, terpenoids, alkaloids, coumarins, tannins, flavonoids, steroids and quinines are involved in the phytotoxic activities of the allelopathic plants [28] [72]. Recently, a number of compounds extracted from higher plants, such as cineole, benzoxazinones, quinolinic acid and leptospermones, have been commercially applied in crop fields to control weeds such as Benzoxazinones and Quinolinic acid by BASF, Germany; Cineole as Cinmethylene by Shell, USA; Letospermones as Triketones by Zeneca, Letospermones as Mesotrione by Syngenta AG [73] [100] [101] [102]. A brief description of the natural products (plant extracts or essential oils) commercially used in the crop fields is summarized in Table 1.

Moreover, these herbicides are not quite enough to control a vast number of weeds, and also not effective to all weeds. Therefore, searching of new natural plant products effective for weed control is very crucial. Isolation and identification of new natural plant products might lead to the development of new natural herbicides.

\section{Challenge for Medicinal Plant Allelopathy in Weed Management}

Although selection and/or identification of allelopathic plants from medicinals plants are much easier than other group of plants, isolation and identification of 
Table 1. Examples of commercial products containing natural products used for weed management in organic agriculture [102] [103] [104] [105].

\begin{tabular}{|c|c|}
\hline Products & Components \\
\hline $\begin{array}{l}\text { Callisto }^{\circledR}, \text { Tenacity }^{\circledR}, \text { Lumax }^{\circledR}, \text { Lexar }^{\circledR}, \text { Halex } \mathrm{GT}^{\circledR}, \text { Camix }^{\circledR} \text {, } \\
\text { Calaris }^{\circledR} \text {, Callisto Xtra } \\
\text { or Elumis }^{\circledR}\end{array}$ & $\begin{array}{l}\text { Leptospermone (1-hydroxy-2-isovaloryl-4,4,6,6-tetramethyl } \\
\text { cyclohexen-3,5-dione) which is produced by the roots of the Callistemon citrinus }\end{array}$ \\
\hline WeedBan $^{\mathrm{TM}}$, Corn Weed Blocker ${ }^{\mathrm{TM}}$ & Corn gluten meal \\
\hline Bioscape Bioweed $^{\mathrm{TM}}$ & Corn gluten meal, soybean \\
\hline Scythe ${ }^{\mathrm{TM}}$ & $\begin{array}{l}\text { Pelargonic acid }(57 \%) \text {, related short chain fatty acids }(3 \%), 30 \% \text { paraffinic } \\
\text { petroleum oil }(30 \%)\end{array}$ \\
\hline Burnout $^{\mathrm{TM}}$, Bioganic ${ }^{\mathrm{TM}}$, Poison Ivy Defoliant ${ }^{\mathrm{TM}}$ & $\begin{array}{l}\text { Clove oil }(12 \%-18 \%) \text {, sodium lauryl sulfate }(8 \%-10 \%) \text {, acetic acid, lecithin, citric } \\
\text { acid }(30 \%) \text {, mineral oil }(80 \%)\end{array}$ \\
\hline Bioorganic $^{\mathrm{TM}}$ & $\begin{array}{l}\text { Clove oil (5\%), 2-phenethyl propionate (5\%), sesame oil (4\%) and sodium lauryl } \\
\text { sulfate }(0.5 \%)\end{array}$ \\
\hline AllDown ${ }^{\mathrm{TM}}$ & Citric acid (5\%), acetic acid, yucca extracts, garlic oil (0.2\%) \\
\hline Interceptor ${ }^{\mathrm{TM}}$ & $10 \%$ pine oil \\
\hline Weed Zap ${ }^{\mathrm{TM}}$ & Clove oil or cinnamon oil (30\%), vinegar (70\%) \\
\hline Weed-A-Tak ${ }^{\mathrm{TM}}$, Repellex ${ }^{\circledR}$ & $\begin{array}{l}\text { Citric acid ( } 32 \%) \text {, clove oil ( } 8 \%) \text {, cinnamon oil ( } 8 \%), 2 \text {-phenetyl proprionate, } \\
\text { lecithin. It may contain thyme oil, and wintergreen oil }\end{array}$ \\
\hline $\begin{array}{l}\text { Moss \& Algae Killer }{ }^{\mathrm{TM}} \text { Naturell WK Herbicide }{ }^{\mathrm{TM}}, \text { DeMoss }^{\mathrm{TM}} \text {, } \\
\text { Mosskiller }\end{array}$ & Potassium salts of fatty acids ( $40 \%)$ \\
\hline Organic Weed \& Grass Killer ${ }^{\mathrm{TM}}$ & Citrus oil (70\%) \\
\hline GreenMatch $\mathrm{O}^{\mathrm{TM}}$, Nature's Avenger ${ }^{\mathrm{TM}}$ & D -Limonene ( $70 \%)$, castor oil ( $1 \%$ to $4 \%)$, emulsifiers ( $18 \%$ to $23 \%)$ \\
\hline GreenMatch EX ${ }^{\mathrm{TM}}$ & $\begin{array}{l}\text { Lemongrass oil ( } 50 \%) \text { and a mixture of water, corn oil, glycerol esters, potassium } \\
\text { oleate and lecithin }\end{array}$ \\
\hline Matran II ${ }^{\mathrm{TM}}$ & Clove oil (46\%), wintergreen oil, butyl lactate, lecithin \\
\hline Eco-Exempt ${ }^{\mathrm{TM},}$ Eco-Smart ${ }^{\mathrm{TM}}$ & 2-Phenethyl proprionate (21.4\%), clove oil (21.4\%) \\
\hline Basta $^{\circledR}$, Buster $^{\circledR}$, Challenge $^{\circledR}$, Finale ${ }^{\circledR}$, Harvest $^{\circledR}$, Ignite ${ }^{\circledR}$, Rely $^{\circledR}$, & Phosphinothricin $[\mathrm{PPT}$ or glufosinate $=$ \\
\hline Liberty $^{\circledR}$ & L- 2-amino-4-(hydroxymethylphosphinyl) butyric acid] \\
\hline PORGANIC ${ }^{\mathrm{TM}}$ & Leaf extracts of Aglaia odorata \\
\hline
\end{tabular}

strong allelopathic substance is laborious, time consuming and need very sophisticated equipment's. Hence, to date very few works have been conducted to isolate and characterize the allelopathic substances from allelopathic medicinal plants. A list of allelopathic substances isolated from different medicinal plants is given in Table 2. These substances showed strong phytotoxic potential against different target plant species under laboratory condition. However, their phytotoxic potential under field condition not yet reported. It is well known that even a substance showing strong phytotoxic activity on target plants in laboratory experiments, may not perform satisfactorily in the field conditions due to the influence of several soil factors like soil $\mathrm{pH}$, organic carbon, organic matter and available nitrogen [136] [137] [138] [139]. Therefore, more emphasis should be 
Table 2. Isolated compound of different medicinal plants and their phytotoxicity against test plant species.

\begin{tabular}{|c|c|c|c|c|c|}
\hline $\begin{array}{l}\text { Sl. } \\
\text { No. }\end{array}$ & $\begin{array}{l}\text { Plants } \\
\text { species }\end{array}$ & Family name & Compound isolated & Phytotoxicity on test plants & Authors \\
\hline 1 & Citrus junos & Rutaceae & $\begin{array}{l}\text { Abscisic acid- } \beta \text {-d-glucopyranosyl } \\
\text { ester }\end{array}$ & $\begin{array}{l}\text { The concentrations required for } 50 \% \text { inhibition } \\
\left(I C_{50}\right) \text { of the shoot and root growth of lettuce } \\
\text { was } 2.3 \text { and } 1.4 \mu \mathrm{M} \text {, respectively. }\end{array}$ & $\begin{array}{l}\text { Kato-Noguc } \\
\text { hi et al. [106] }\end{array}$ \\
\hline 2 & $\begin{array}{l}\text { Hibiscus } \\
\text { sabdariffa }\end{array}$ & Malvaceae & Trimethyl allo-hydroxycitrate & $\begin{array}{l}I C_{50} \text { value for the shoot and root growth of garden } \\
\text { cress was } 20.3 \text { and } 14.4 \mathrm{mM} \text {, respectively. }\end{array}$ & $\begin{array}{l}\text { Suwitchayan } \\
\text { on et al. } \\
\text { [107] }\end{array}$ \\
\hline 3 & $\begin{array}{l}\text { Ailanthus } \\
\text { altissima }\end{array}$ & Simaroubaceae & Ailanthone & $\begin{array}{l}I C_{50} \text { value for the radicle elongation of } \\
\text { garden cress was } 0.7 \mathrm{~mL} \mathrm{~L}^{-1}\end{array}$ & Heisey [108] \\
\hline 4 & Leucas aspera & Lamiaceae & $\begin{array}{l}\text { 3:2 mixture of two labdane type } \\
\text { diterpenes [(rel } \\
\text { 5S,6R,8R,9R,10S,13S,15S,16R)-6-aceto } \\
\text { xy-9,13;15,16-diepoxy-15-hydroxy-16- } \\
\text { methoxylabdane and (rel } \\
\text { 5S,6R,8R,9R,10S,13S,15R,16R)-6-aceto } \\
\text { xy-9,13;15,16-diepoxy-15-hydroxy-16- } \\
\text { methoxylabdane] }\end{array}$ & $\begin{array}{l}I C_{50} \text { value for the seedling growth of garden cress } \\
\text { and barnyard grass ranges from } 31 \text { to } 80 \mu \mathrm{M} \text {. }\end{array}$ & $\begin{array}{l}\text { Islam et al. } \\
\text { [109] }\end{array}$ \\
\hline 5 & $\begin{array}{l}\text { Hyptis } \\
\text { suaveolens }\end{array}$ & Lamiaceae & $\begin{array}{l}\text { 14 } \alpha \text {-hydroxy-13 } \beta \text {-abiet-8-en-18-oic } \\
\text { acid (suaveolic acid) }\end{array}$ & $\begin{array}{l}I C_{50} \text { value for the growth inhibition of suaveolic } \\
\text { acid for garden cress, Italian ryegrass, and } \\
\text { barnyard grass were ranged from } 76 \text { to } 1155 \mu \mathrm{M} \text {. }\end{array}$ & $\begin{array}{l}\text { Islam et al. } \\
\text { [110] }\end{array}$ \\
\hline 6 & $\begin{array}{l}\text { Mangifera } \\
\text { indica }\end{array}$ & Anacardiaceae & $\begin{array}{l}\text { Methyl-3,4,5-trihydroxybenzoate } \\
\text { (methyl gallate) }\end{array}$ & $\begin{array}{l}I C_{50} \text { value for the growth inhibition of garden } \\
\text { cress roots and shoots were } 3.9 \text { and } 3.3 \mathrm{mM} \text {, } \\
\text { and those of foxtail fescue roots and shoots } \\
\text { were } 1.5 \text { and } 9.5 \mathrm{mM} \text {, respectively. }\end{array}$ & $\begin{array}{l}\text { Suzuki et al. } \\
\text { [111] }\end{array}$ \\
\hline 8 & $\begin{array}{l}\text { Peganum } \\
\text { harmala }\end{array}$ & Nitrariaceae & Harmaline & $\begin{array}{l}\text { Inhibiting root elongation of lettuce and amaranth } \\
\text { by } 31 \% \text { and } 47 \% \text { at a } 5 \mu \mathrm{g} \mathrm{mL} \mathrm{m}^{-1} \text { concentration }\end{array}$ & $\begin{array}{l}\text { Shao et al. } \\
{[113]}\end{array}$ \\
\hline 9 & $\begin{array}{l}\text { Azadirachta } \\
\text { indica }\end{array}$ & Meliaceae & Nimbolide B and Nimbic acid B. & $\begin{array}{l}\text { In case of Nimbolide } B \text { the } I C_{50} \text { value for growth } \\
\text { inhibition of cress roots and shoots was } 1.2 \text { and } \\
1.4 \mu \mathrm{M} \text { and that of barnyard grass roots and } \\
\text { shoots were } 3.7 \text { and } 39 \mu \mathrm{M} \text {, respectively. } \\
\text { In case of Nimbic acid B the } I C_{50} \text { value for the cress } \\
\text { roots and shoots were } 5.7 \text { and } 9.4 \mu \mathrm{M} \text {, respectively, } \\
\text { and } \mathrm{I}_{50} \text { of the barnyard grass roots and shoots were } \\
29 \text { and } 210 \mu \mathrm{M} \text {, respectively. }\end{array}$ & $\begin{array}{l}\text { Kato-Noguc } \\
\text { hi et al. }\end{array}$ \\
\hline 10 & $\begin{array}{l}\text { Zanthoxylum } \\
\text { limonella }\end{array}$ & Rutaceae & Xanthoxyline & $\begin{array}{l}\text { At a concentration of } 2500 \mu \mathrm{M} \text {, xanthoxyline } \\
\text { completely inhibited seed germination and growth } \\
\text { of Chinese amaranth, while seed germination, shoot } \\
\text { and root length of barnyard grass were inhibited by } \\
44,72 \text { and } 88 \% \text {, respectively by this compound. }\end{array}$ & $\begin{array}{l}\text { Charoenying } \\
\text { et al. [115] }\end{array}$ \\
\hline 11 & $\begin{array}{l}\text { Aglaia } \\
\text { odorata }\end{array}$ & Meliaceae & Odorine, Rocaglaol & $\begin{array}{l}\text { Odorine at concentration of } 8000 \text { ppm showed } 79 \% \\
\text { reduction of barnyard grass germination, and } \\
\text { exhibited seedling growth inhibition at all tested } \\
\text { concentrations (1000, } 2000,4000 \text { and } 8000 \text { ppm). } \\
\text { The } I C_{50} \text { value of Rocaglaol for garden cress and } \\
\text { barnyard grass ranged from } 0.09 \text { to } 2.5 \mu \mathrm{M} \text {. }\end{array}$ & $\begin{array}{l}\text { Kato-Noguc } \\
\text { hi et al. } \\
\text { [103], } \\
\text { Teerarak et } \\
\text { al. }[116]\end{array}$ \\
\hline
\end{tabular}




\section{Continued}

12 Orthosiphon Lamiaceae stamineus

13 Asparagus Asparagaceae officinalis 13-epi-orthosiphol N

(2)

The $I C_{50}$ value of this compound for seedling growth of garden cress and lettuce ranged from 41 to $102 \mu \mathrm{mol} \mathrm{L}-1$

p-Coumaric acid, iso-Agatharesinol and p-Coumaric acid and iso-Agatharesinol inhibited trans-Cinnamic acid

the shoot and root growth of asparagus, garden cress and ryegrass, at concentrations higher than 0.1 $\mathrm{mM}$. The $I C_{50}$ value for the root and shoot growth of these test plants ranged from 0.36 to $0.85 \mathrm{mM}$ and 0.41 to $1.22 \mathrm{mM}$ for $\mathrm{p}$-Coumaric acid and iso-Agatharesinol, respectively.

trans-Cinnamic acid inhibited the growth of asparagus seedlings at concentrations greater than $10 \mu \mathrm{M}$. The $I C_{50}$ value of the compound for growth inhibition of asparagus was $24.1-41.6 \mu \mathrm{M}$.
14 Piper Piperaceae methysticum annuus nardus
Chrysanthem Asteraceae um morifolium
Myrislignan, N-Octanoyl tyramine

2-Methoxystypandrone, 5,7-dihydroxyphthalide and altechromone $\mathrm{A}$.
Inhibited the seedling growth of cat's-eyes by about 15-dinor-3-hydroxy-1(5)-xanthene-12,8 50\% at a concentration of $30 \mathrm{ppm}$. -olide (sundiversifolide)

3-3' -5-Trihydroxy-

4'-7-dimethoxyflavone and 3-3'-5-Trihydroxy-4'-7-dimethoxyflavo Napa cabbage and Ligularia virgaurea (a weed) ne-3-O-sulfate

Luteolin 7-O- $\beta$-glucuronide

At concentrations of 0.2 and $2.0 \mathrm{mM}$, the compound reduced the frond number and chlorophyll content of Lemna gibba

$I C_{50}$ value of Myrislignan for the shoot and root growth of garden cress was 429 and $517 \mu \mathrm{M}$, respectively.

$I C_{50}$ values of $N$-octanoyl tyramine were 426 and 444 $\mu \mathrm{M}$ for shoot and root growth of cress, and that for barnyard grass was 1430 and $450 \mu \mathrm{M}$, respectively.

$I C_{50}$ values of 2-Methoxystypandrone for growth inhibition of Garden cress was ranged from 5.8 to $11.8 \mu \mathrm{M}$.

$I C_{50}$ values for the growth inhibition of garden cress seedling growth were $1.73-2.48 \mathrm{mM}$ for 5 , 7-dihydroxyphthalide and $0.66-1.41 \mathrm{mM}$ for altechromone A, respectively.

$I C_{50}$ values of methyl gallate for the growth of garden cress and barnyard grass ranged from 2.3 to 2.9 and 0.3 to $30.5 \mathrm{mM}$, respectively.
Methyl gallate
Kato-Noguc hi et al.

[117]

Kato-Noguc hi et al. [118], Kato-Noguc hi et al. [119]

Van et al. [120] Ohno et al. [121] Ma et al. [122]

Beninger and Hall [123] Suwitchayan on et al. [124], Suwitchayan on et al. [125]

Islam et al. [126], Islam et al. [127]
20 mimosoides 


\section{Continued}

\begin{tabular}{|c|c|c|c|c|c|}
\hline 21 & $\begin{array}{l}\text { Ginkgo } \\
\text { biloba }\end{array}$ & Ginkgoaceae & $\begin{array}{l}\text { 2-hydroxy-6-(10-hydroxypentadec-11-e } \\
\text { nyl)benzoic acid }\end{array}$ & $\begin{array}{l}\text { The } I C_{50} \text { values of the compound for seedling } \\
\text { growth inhibition for garden cress roots and } \\
\text { shoots were } 9.1 \text { and } 12 \mathrm{M} \text {, respectively, and } \\
\text { that for timothy roots and shoots was } 17 \text { and } 23 \mathrm{M} \text {, } \\
\text { respectively. The activity of the compound was } \\
10 \text { - to } 52 \text {-fold that of nonanoic acid (a natural ester } \\
\text { used for herbicide preparation) on those test } \\
\text { species. }\end{array}$ & $\begin{array}{l}\text { Kato-Noguc } \\
\text { hi et al. } \\
{[129]}\end{array}$ \\
\hline 22 & $\begin{array}{l}\text { Cucumis } \\
\text { sativus }\end{array}$ & Cucurbitaceae & $\begin{array}{l}\text { 9-hydroxy-4,7-megastigmadien-9-one } \\
\text { (1); } \\
\text { (6S,7E,9S)-6,9,10-trihydroxy-4,7-megast } \\
\text { igmadien-3-one (2); } \\
\text { (2S)-2,3-dihydro-2a-(4-hydroxy-3-meth } \\
\text { oxyphenyl)-7- } \\
\text { methoxy-5-(1,2,3-trihydroxypropyl)ben } \\
\text { zofuran-3b-methanol (sisymbrifolin, 3) }\end{array}$ & $\begin{array}{l}\text { The } I C_{50} \text { values for root and shoot growth } \\
\text { inhibition of cress and barnyard grass were } 2.4 \text { - } \\
29.3 \mu \mathrm{M} \text { for compound } 1 \text { and } 8.1-52.2 \mu \mathrm{M} \text { for } \\
\text { compound } 2 \text {. } \\
\text { The } I C_{50} \text { values of compound } 3 \text { for root and shoot } \\
\text { growth inhibition of cress and barnyard grass were } \\
16.534 .2 \mu \mathrm{M} \text { and } 22.1-67.3 \mu \mathrm{M} \text {, respectively. }\end{array}$ & $\begin{array}{l}\text { Kato-Noguc } \\
\text { hi et al. } \\
{[130] \text {, }} \\
\text { (Kato-Nogu } \\
\text { chi et al. } \\
\text { [131] }\end{array}$ \\
\hline 23 & $\begin{array}{l}\text { Rhinacanthus } \\
\text { nasutus }\end{array}$ & s Acanthaceae & $\begin{array}{l}\text { 4-hydroxy-3-methoxybenzoic acid } \\
\text { (vanillic acid) }\end{array}$ & $\begin{array}{l}\text { The } I C_{50} \text { values of vanillic acid for growth } \\
\text { inhibition of cress and lettuce were about } 470-800 \\
\mu \mathrm{M} \text { and that for timothy and Italian ryegrass were } \\
0.17-8.2 \mu \mathrm{M} \text {, respectively. }\end{array}$ & $\begin{array}{l}\text { Piyatida et } \\
\text { al. [132] }\end{array}$ \\
\hline 24 & $\begin{array}{l}\text { Tinospora } \\
\text { tuberculata }\end{array}$ & Menispermaceae & $\begin{array}{l}\text { 4-[(1E)-3-Hydroxyprop-1-en-1-yl]-2,6- } \\
\text { dimethoxyphenyl b-D-glucopyranoside } \\
\text { (syringing) }\end{array}$ & $\begin{array}{l}\text { The } I C_{50} \text { values of syringing for root and shoot } \\
\text { growth inhibition of garden cress and lettuce } \\
\text { ranged from } 78.2 \text { to } 412 \mu \mathrm{M} \text {, and that of timothy } \\
\text { and barnyard grass ranged from } 9.8 \text { to } 73.2 \mu \mathrm{M} \text {, } \\
\text { respectively. }\end{array}$ & $\begin{array}{l}\text { Kato-Noguc } \\
\text { hi et al. } \\
{[133]}\end{array}$ \\
\hline 25 & $\begin{array}{l}\text { Piper } \\
\text { sarmentosum }\end{array}$ & Piperaceae & 3-phenylpropionic acid & $\begin{array}{l}\text { The } I C_{50} \text { values of 3-phenylpropionic acid for cress } \\
\text { and lettuce were } 1.2-9.3 \mu \mathrm{M} \text { and that of timothy } \\
\text { and Italian ryegrass were } 4.7-51.8 \mu \mathrm{M} \text {, respectively. }\end{array}$ & $\begin{array}{l}\text { Piyatida et } \\
\text { al. }[134]\end{array}$ \\
\hline 26 & $\begin{array}{l}\text { Onopordum } \\
\text { acanthium }\end{array}$ & Asteraceae & $\begin{array}{l}\text { Elemanolide 11(13)-dehydromelitensin } \\
\text { b-hydroxyisobutyrate }\end{array}$ & Inhibited the coleoptile growth of wheat. & $\begin{array}{l}\text { Watanabe et } \\
\text { al. [135] }\end{array}$ \\
\hline
\end{tabular}

given on evaluating the bioactivity of allelopathic substances or the allelopathic plant extracts in both laboratory and field condition. If the extracts or the isolated compound shows strong activity in both conditions only then it could be recommend for new natural herbicide development.

\section{Conclusion}

From the above discussion, it is clear that there is immense prospect of allelopathic medicinal plants for the isolation and identification of allelochemicals and applies them as a tool for new bio-herbicide development. On the other hand, issues such as environmental pollution, unsafe agricultural products, human health concerns, may be dealt appropriately if allelopathic medicinal plants or bio-herbicides developed from their allelochemicals are use in the crop fields for weed management instead of synthetic herbicides. Undoubtedly, these natural products based crop production system will continue to attract increasing attention and, ultimately, will play a major role in agricultural productivity in a most 
sustainable way. However, before implication of allelochemicals as bio-herbicide the following points should be considered:

1) both laboratory and field experiments should be conducted exclusively, to study its interaction with various physical, chemical and biological properties of soil.

2) the physiological and ecological mechanisms of allelopathy for example, the movement of allelochemicals, its fate in soil, mode of action, selectivity etc. should be studied.

3) the impact of use of allelochemicals from agronomic and environmental point of view should be brought under consideration. However, allelochemicals are not always safe for the human and animals. There are some allelochemicals that are toxic to human beings and are carcinogenic, for example, AAL-toxin and fumonisin are toxic to mammalian cells [19]. Some other allelochemicals are reported to cause dermatitis [140].

If the identified allelochemicals satisfy the above three criteria then it could be used for the development of natural herbicides. Moreover, except very few limitation, natural product based agriculture is the only way to achieve sustainable crop production for the pollution free green earth ecosystems. Allelopathic medicinal plants could provide the clues to the researchers of that arena and still there is a lot of vacant space for the scientists to work with allelopathic medicinal plants. Therefore, in future more and more emphasis should be given by the researchers to isolate and identify the new allelopathic substances from the medicinal plants, examine their bioactivity under laboratory and field conditions, if satisfy both then recommend them to use as a tool for new natural herbicides development for the evergreen world.

\section{Conflicts of Interest}

The authors declare no conflicts of interest regarding the publication of this paper.

\section{References}

[1] Swarbrick, J.T. and Mercado, B.L. (1987) Weed Science and Weed Control in Southeast Asia: An Introductory Text for Students of Agriculture in Southeast Asia, Vol. 81. Food \& Agriculture Org., Rome.

[2] Oerke, E.C. and Dehne, H.W. (1997) Global Crop Production and the Efficacy of Crop Protection-Current Situation and Future Trends. European Journal of Plant Pathology, 103, 203-215. https://doi.org/10.1023/A:1008602111248

[3] Karim, S.M.R. (1998) Relative Yields of Crops and Crop Losses Due to Weed Competition in Bangladesh. Pakistan Journal of Science and Industrial Research, 41, 318-324.

[4] Mamun, A.A. (1990) Agro-Ecological Studies of Weeds and Weed Control in a Flood Prone Village of Bangladesh. JSARD pub, 17, 28-29.

[5] Samson, J. (2006) Roundup Ready Corn: A Newly Approved Agbiotech Product for Filipino Corn Farmers. In: 4th Philippine National Corn Congress, Pangasinan, 4-5 May 2006. 
[6] Aktar, W., Sengupta, D. and Chowdhury, A. (2009) Impact of Pesticides Use in Agriculture: their Benefits and Hazards. Interdisciplinary Toxicology, 2, 1-12. https://doi.org/10.2478/v10102-009-0001-7

[7] Wilson, C. and Tisdell, C. (2001) Why Farmers Continue to Use Pesticides despite Environmental, Health and Sustainability Costs. Ecological Economics, 39, 449-462. https://doi.org/10.1016/S0921-8009(01)00238-5

[8] Pell, M., Stenberg, B. and Torstensson, L. (1998) Potential Denitrification and Nitrification Tests for Evaluation of Pesticide Effects in Soil. Ambio, 27, 24-28.

[9] Heap, I. (2018) International Survey of Herbicide Resistant Weeds. http://www.weedscience.org/

[10] IAS (2018) International Allelopathy Society. http://allelopathy-society.osupytheas.fr/about/

[11] Rice, E.L. (1984) Allelopathy. Academic Press, Orlando.

[12] Weir, T.L. Park, S.W. and Vivanco, J.M. (2004) Biochemical and Physiological Mechanisms Mediated by Allelochemicals. Current Opinion in Plant Biology, 7, 472-479. https://doi.org/10.1016/j.pbi.2004.05.007

[13] Yu, J.Q., Ye, S.F., Zhang, M.F. and Hu, W.H. (2003) Effects of Root Exudates and Aqueous Root Extracts of Cucumber (Cucumis sativus) and Allelochemicals, on Photosynthesis and Antioxidant Enzymes in Cucumber. Biochemical Systematics and Ecology, 31, 129-139. https://doi.org/10.1016/S0305-1978(02)00150-3

[14] Meier C.L. and Bowman, W.D. (2008) Phenolic-Rich Leaf Carbon Fractions Differentially Influence Microbial Respiration and Plant Growth. Oecologia, 158, 95-107. https://doi.org/10.1007/s00442-008-1124-9

[15] Xingjun Y.U., Yu, D., Zhijun, L.U. and Keping, M.A. (2005) A New Mechanism of Invader Success: Exotic Plant Inhibits Natural Vegetation Restoration by Changing Soil Microbe Community. Chinese Science Bulletin, 50, 1105-1112. https://doi.org/10.1360/04WC0280

[16] Zhou, B., Kong, C.H., Li, Y.H., Wang, P. and Xu, X.H. (2013) Crabgrass (Digitaria sanguinalis) Allelochemicals That Interfere with Crop Growth and the Soil Microbial Community. Journal Agriculture Food Chemistry, 61, 5310-5317. https://doi.org/10.1021/jf401605g

[17] Smith, A.E. and Martin, L.D. (1994) Allelopathic Characteristics of Three Cool-Season Grass Species in the Forage Ecosystem. Agronomy Journal, 86, 243-246. https://doi.org/10.2134/agronj1994.00021962008600020006x

[18] Vyvyan, J.R. (2002) Allelochemicals as Leads for New Herbicides and Agrochemicals. Tetrahedron, 58, 1631-1646. https://doi.org/10.1016/S0040-4020(02)00052-2

[19] Duke, S.O., Dayan, F.E., Romagni, J.G. and Rimando, A.M. (2000) Natural Products as Sources of Herbicides: Current Status and Future Trends. Weed Research, 40, 99-111. https://doi.org/10.1046/j.1365-3180.2000.00161.x

[20] Kamboj, V.P. (2000) Herbal Medicine. Current Science, 78, 35-39.

[21] Verma, S. and Singh, S.P. (2008) Current and Future Status of Herbal Medicines. Veterinary World, 1, 347-350. https://doi.org/10.5455/vetworld.2008.347-350

[22] Mukherjee, P.K., Ponnusankar, S. and Venkatesh, M. (2010) Ethno Medicine in Complementary Therapeutics. In: Chattopadhyay, D., Ed., Ethnomedicine: $A$ Source of Complementary Therapeutics, Research Signpost, 29-52.

[23] Wakdikar, S. (2004) Global Health Care Challenge: Indian Experiences and New Prescriptions. Electronic Journal of Biotechnology, 7, 2-3. 
[24] Verpoorte, R. (2000) Pharmacognosy in the New Millennium: Leadfinding and Biotechnology. Journal of Pharmacy and Pharmacology, 52, 253-262. https://doi.org/10.1211/0022357001773931

[25] Appiah, K.S., Mardani, H.K., Osivand, A., Kpabitey, S. Amoatey, C.A., Oikawa, Y. and Fujii, Y. (2017) Exploring Alternative Use of Medicinal Plants for Sustainable Weed Management. Sustainability, 9, 1468. https://doi.org/10.3390/su9081468

[26] Fabricant, D.S. and Farnsworth, N.R. (2001) The Value of Plants Used in Traditional Medicine for Drug Discovery. Environmental Health Perspectives, 109, 69-75.

[27] Swain, T. (1977) Secondary Compounds as Protective Agents. Annual Review of Plant Physiology, 28, 479-501. https://doi.org/10.1146/annurev.pp.28.060177.002403

[28] Einhellig, F.A. and Leather, G.R. (1988) Potentials for Exploiting Allelopathy to Enhance Crop Production. Journal Chemical Ecology, 14, 1829-1844. https://doi.org/10.1007/BF01013480

[29] Chevallier, A. (1996) The Encyclopedia of Medicinal Plants: A Practical Reference Guide to over 550 Key Herbs \& Their Medicinal Uses. Dorling Kindersley, London.

[30] Wink, M. (1999) Introduction: Biochemistry, Role and Biotechnology of Secondary Metabolites. Annual Plant Reviews, 1-16.

[31] Qasem, J.R. (2002) Allelopathic Effects of Selected Medicinal Plants on Amaranthus retroflexus and Chenopodium murale. Allelopathy Journal, 10, 105-122.

[32] Azizi, M. and Fuji, Y. (2006) Allelopathic Effect of Some Medicinal Plant Substances on Seed Germination of Amaranthus retroflexus and Portulaca oleraceae. Acta Horticultare, 699, 61-67. https://doi.org/10.17660/ActaHortic.2006.699.5

[33] Lin, D., Tsuzuki, E., Sugimoto, Y., Dong, Y., Matsuo, M. and Terao, H. (2003) Assessment of Dwarf Lilyturf (Ophiopogon japonicus K.) Dried Powders for Weed Control in Transplanted Rice. Crop Protection, 22, 431-435.

https://doi.org/10.1016/S0261-2194(02)00190-4

[34] Lin, D., Tsuzuki, E., Sugimoto, Y., Dong, Y., Matsuo, M. and Terao, H. (2004) Elementary Identification and Biological Activities of Phenolic Allelochemicals from Dwarf Lilyturf Plant (Ophiopogon japonicus K.) against Two Weeds of Paddy Rice field. Plant Production Science, 7, 260-265. https://doi.org/10.1626/pps.7.260

[35] Han, C.M., Pan, K.W., Wu, N., Wang, J.C. and Li, W. (2008) Allelopathic Effect of Ginger on Seed Germination and Seedling Growth of Soybean and Chive. Scientia Horticulture (Amsterdam), 116, 330-336. https://doi.org/10.1016/j.scienta.2008.01.005

[36] Li, H., Pan, K., Liu, Q. and Wang, J. (2009) Effect of Enhanced Ultraviolet-B on Allelopathic Potential of Zanthoxylum bungeanum. Scientia Horticulture (Amsterdam), 119, 310-314. https://doi.org/10.1016/j.scienta.2008.08.010

[37] Sodaeizadeh, H., Rafieiolhossaini, M., Havlík, J. and van Damme, P. (2009) Allelopathic Activity of Different Plant Parts of Peganum harmala L. and Identification of Their Growth Inhibitors Substances. Plant Growth Regulation, 59, 227-236. https://doi.org/10.1007/s10725-009-9408-6

[38] Islam, A.K.M.M. and Kato-Noguchi, H. (2014) Phytotoxic Activity of Ocimum tenuiflorum Extracts on Germination and Seedling Growth of Different Plant Species. The Scientific World Journal, 2014, Article ID: 676242. https://doi.org/10.1155/2014/676242

[39] Fujii, Y., Parvez, S.S., Parvez, M.M., Ohmae, Y. and Uda, O. (2003) Screening of 239 Medicinal Plant Species for Allelopathic Activity Using the Sandwich Method. 
Weed Biology Management, 3, 233-241.

https://doi.org/10.1046/j.1444-6162.2003.00111.x

[40] Fujii, Y., Shibuya, T. and Yasuda, T. (1990) Survey of Japanese Weeds and Crops for the Detection of Water-Extractable Allelopathic Chemicals Using RICHARDS' Function Fitted to Lettuce Germination Test. Weed Research, 35, 362-370.

[41] Fujii, Y., Furukawa, M., Hayakawa, Y., Sugahara, K. and Shibuya, T. (1991) Survey of Japanese Medicinal Plants for the Detection of Allelopathic Properties. Journal of Weed Science and Technology, 36, 36-42.

[42] Azizi, M., Amini, S., Joharchi, M.R., Oroojalian, F. and Baghestani, Z. (2009) Genetic Resources for Allelopathic and Medicinal Plants from Traditional Persian Experience. MARCO Symposium (Challenges for Agro-Environmental Research in Monsoon Asia), Tsukuba, Japan.

[43] Gilani, S.A., Fujii, Y., Shinwari, Z.K., Adnan, M., Kikuchi, A. and Watanabe, K.N. (2010) Phytotoxic Studies of Medicinal Plant Species of Pakistan. Pakistan Journal of Botany, 42, 987-996.

[44] Mardani, H., Azizi, M., Osivand, A. and Fujii, Y. (2014) Evaluation of Allelopathic Activity of Iranian Medicinal Plants by Sandwich Method. Journal of Weed Science and Technology (Supplement), 53, 85.

[45] Amini, S., Azizi, M., Joharchi, M.R. and Moradinezhad, F. (2016) Evaluation of Allelopathic Activity of 68 Medicinal and Wild Plant Species of Iran by Sandwich Method. International Journal of Horticultural Science and Technology, 3, 243-253.

[46] Islam, A.K.M.M., Hasan, M., Hasan, M.M., Uddin, K., Juraimi, A.S. and Anwar, MP. (2018) Exploring 55 Tropical Medicinal Plant Species Available in Bangladesh for Their Possible Allelopathic Potentiality. Annals of Agricultural Sciences, 63, 99-107. https://doi.org/10.1016/j.aoas.2018.05.005

[47] Piyatida, P. and Kato-Noguchi, H. (2010) Screening of Allelopathic Activity of Eleven Thai Medicinal Plants on Seedling Growth of Five Test Plant Species. Asian Journal of Plant Science, 9, 486-491. https://doi.org/10.3923/ajps.2010.486.491

[48] Suwitchayanon, P., Kunasakdakul, K. and Kato-Noguchi, H. (2017) Screening the Allelopathic Activity of 14 Medicinal Plants from Northern Thailand. Environmental Control Biology, 55, 143-145.

[49] Khanh, T.D., Hong, N.H., Xuan, T.D. and Chung, I.M. (2005) Paddy Weed Control by Medicinal and Leguminous Plants from Southeast Asia. Crop Protection, 24, 421-431. https://doi.org/10.1016/j.cropro.2004.09.020

[50] Khan, A.L., Hamayun, M., Hussain, J., Khan, H., Gilani, S.A., Kikuchi, A., Watanabe, K.N., Jung, E.H. and Lee, I. (2009) Assessment of Allelopathic Potential of Selected Medicinal Plants of Pakistan. African Journal of Biotechnology, 8, 1024-1029.

[51] Anjum, A., Hussain, U., Yousaf, Z., Khan, F. and Umer, A. (2010) Evaluation of Allelopathic Action of Some Selected Medicinal Plant on Lettuce Seeds by Using Sandwich Method. Journal of Medicinal Plants, 4, 536-541.

[52] Laosinwattana, C., Teerarak, M. and Charoenying, P. (2012) Effects of Aglaia odorata Granules on the Seedling Growth of Major Maize Weeds and the Influence of Soil Type on the Granule Residue's Efficacy. Weed Biology and Management, 12, 117-122. https://doi.org/10.1111/j.1445-6664.2012.00444.x

[53] Islam, A.K.M.M. and Kato-Noguchi, H. (2012) Allelopathic Potentiality of Medicinal Plant Leucas aspera. International Journal of Sustainable Agriculture, 4, 1-7.

[54] Islam, A.K.M.M. and Kato-Noguchi, H. (2013) Mentha sylvestris: A Potential Allelopathic Medicinal Plant. International Journal of Agriculture and Biology, 15, 
1313-1318.

[55] Khan, M.S.I., Islam, A.K.M.M. and Kato-Noguchi, H. (2013) Evaluation of Allelopathic Activity of Three Mango (Mangifera indica) Cultivars. Asian Journal of Plant Science, 12, 252-261. https://doi.org/10.3923/ajps.2013.252.261

[56] Islam, A.K.M.M. and Kato-Noguchi, H. (2013) Plant Growth Inhibitory Activity of Medicinal Plant Hyptis suaveolens. Could Allelopathy Be a Cause? Emirates Journal of Food Agriculture, 25, 692-701. https://doi.org/10.9755/ejfa.v25i9.16073

[57] Islam, A.K.M.M., Khan, M.S.I. and Kato-Noguchi, H. (2013) Allelopathic Activity of Litchi chinensis Sonn. Acta Agriculturae Scandinavica, Section B: Soil \& Plant Science, 63, 669-675.

[58] Islam, A.K.M.M. and Kato-Noguchi, H. (2013) Allelopathic Potential of Five Labiatae Plant Species on Barnyard Grass (Echinochloa crus-galli). Australian Journal of Crop Science, 7, 1369-1374.

[59] Itani, T., Nakahata, Y. and Kato-Noguchi, H. (2013) Allelopathic Activity of Some Herb Plant Species. International Journal of Agriculture and Biology, 15, 1359-1362.

[60] Bali čŁRićnavli ć M. and Ravli ćI. (2015) Allelopathic Effect of Aromatic and Medicinal Plants on Tripleurospermum inodorum (L.) CH Schultz. Herbologia, 15, 41-53.

[61] Qasem, J.R. (2017) A Survey on the Phytotoxicity of Common Weeds, Wild Grown Species and Medicinal Plants on Wheat. Allelopathy Journal, 42, 179-194. https://doi.org/10.26651/allelo.j./2017-42-2-1115

[62] Algandaby, M.M. and El-Darier, S. (2016) Management of the Noxious Weed; $\mathrm{Me}$ dicago polymorpha L. via Allelopathy of Some Medicinal Plants from Taif Region, Saudi Arabia. Saudi Journal of Biological Sciences, 25, 1339-1347.

[63] Pachlatko, J.P. (1998) Natural Products in Crop Protection. Chimia-Zurich, 52, 29-47.

[64] Duke, S.O., Dayan, F.E., Rimando, A.M., Schrader, K.K., Aliotta, G., Oliva, A. and Romagni, J.G. (2002) Chemicals from Nature for Weed Management. Weed Science, 50, 138-151. https://doi.org/10.1614/0043-1745(2002)050[0138:IPCFNF]2.0.CO;2

[65] Fujii, Y. (2001) Screening and Future Exploitation of Allelopathic Plants as Alternative Herbicides with Special Reference to Hairy Vetch. Journal of Crop Production, 4, 257-275. https://doi.org/10.1300/J144v04n02_09

[66] Singh, H.P., Batish, D.R. and Kohli, R.K. (2003) Allelopathic Interactions and Allelochemicals: New Possibilities for Sustainable Weed Management. Critical Reviews in Plant Sciences, 22, 239-311. https://doi.org/10.1080/713610858

[67] Hong, N.H., Xuan, T.D., Eiji, T., Hiroyuki, T., Mitsuhiro, M. and Khanh, T.D. (2003) Screening for Allelopathic Potential of Higher Plants from Southeast Asia. Crop Protection, 22, 829-836. https://doi.org/10.1016/S0261-2194(03)00051-6

[68] Yang, R.Z. and Tang, C.S. (1988) Plants Used for Pest Control in China: A Literature Review. Economic Botany, 42, 376-406. https://doi.org/10.1007/BF02860162

[69] Netzly, D.H. and Butler, L.G. (1986) Roots of Sorghum Exude Hydrophobic Droplets Containing Biologically Active Components. Crop Science, 26, 775-778. https://doi.org/10.2135/cropsci1986.0011183X002600040031x

[70] Rimando, A.M., Dayan, F.E., Czarnota, M.A., Weston, L.A. and Duke, S.O. (1998) A New Photosystem II Electron Transfer Inhibitor from Sorghum bicolor. Journal of Natural Products, 61, 927-930. https://doi.org/10.1021/np9800708 
[71] Tellez, M.R., Canel, C., Rimando, A.M. and Duke, S.O. (1999) Differential Accumulation of Isoprenoids in Glanded and Glandless Artemisia annua L. Phytochemistry, 52, 1035-1040. https://doi.org/10.1016/S0031-9422(99)00308-8

[72] Kohli, R.K., Batish, D. and Singh, H.P. (1997) Allelopathy and Its Implications in Agroecosystems. Journal of Crop Production, 1, 169-202.

https://doi.org/10.1300/J144v01n01_08

[73] Macías, F.A., Molinillo, J.M.G., Varela, R.M. and Galindo, J.C.G. (2007) Allelopathy-A Natural Alternative for Weed Control. Pest Management Science, 63, 327-348. https://doi.org/10.1002/ps.1342

[74] Caamal-Maldonado, J.A., Jiménez-Osornio, J.J., Torres-Barragán, A. and Anaya, A.L. (2001) The Use of Allelopathic Legume cover and Mulch Species for Weed Control in Cropping Systems. Agronomy Journal, 93, 27-36. https://doi.org/10.2134/agronj2001.93127x

[75] Milchunas, D.G., Vandever, M.W., Ball, L.O. and Hyberg, S. (2011) Allelopathic Cover Crop Prior to Seeding Is More Important than Subsequent Grazing/Mowing in Grassland Establishment. Rangeland Ecology and Management, 64, 291-300. https://doi.org/10.2111/REM-D-10-00117.1

[76] Urbano, B., Gonzalez-Andres, F. and Ballesteros, A. (2006) Allelopathic Potential of Cover Crops to Control Weeds in Barley. Allelopathy Journal, 17, 53-64.

[77] Putnam, A.R. and Duke, W.B. (1978) Allelopathy in Agroecosystems. Annual Review of Phytopathology, 16, 431-451. https://doi.org/10.1146/annurev.py.16.090178.002243

[78] Habib, S.A. and Rahman, A.A.A. (1988) Evaluation of Some Weed Extracts against Field Dodder on Alfalfa (Medicago sativa). Journal of Chemical Ecology, 14, 443-452. https://doi.org/10.1007/BF01013896

[79] Khaliq, A., Aslam, Z. and Cheema, Z.A. (2002) Efficacy of Different Weed Management Strategies in Mungbean (Vigna radiata L.). International Journal of Agriculture and Biology, 4, 237-239.

[80] Iqbal, J. and Cheema, Z.A. (2007) Effect of Allelopathic Crops Water Extracts on Glyphosate Dose for Weed Control in Cotton (Gossypium hirsutum). Allelopathy Journal, 19, 403-410.

[81] Jabran, K., Farooq, M., Hussain, M., Rehman, H. and Ali, M.A. (2010) Wild Oat (Avena fatua L.) and Canary Grass (Phalaris minor Ritz.) Management through Allelopathy. Journal of Plant Protection Research, 50, 41-44. https://doi.org/10.2478/v10045-010-0007-3

[82] Putnam, A.R. (1988) Allelochemicals from Plants as Herbicides. Weed Technology, 2, 510-518. https://doi.org/10.1017/S0890037X00032371

[83] Barnes, J.P. and Putnam, A.R. (1983) Rye Residues Contribute Weed Suppression in No-Tillage Cropping Systems. Journal of Chemical Ecology, 9, 1045-1057. https://doi.org/10.1007/BF00982210

[84] Cheema, Z.A., Rakha, A. and Khaliq, A. (2000) Use of Sorgaab and Sorghum Mulch for Weed Management in Mungbean. Pakistan Journal of Agricultural Science, 37, 140-144.

[85] Lovett, J.V. (1990) Chemicals in Plant Protection Is There a Natural Alternatives. In: Bassett, C., Whitehouse, L.J. and Zabkiewicz, J.A., Eds., Alternatives to the Chemical Control of Weeds, Forest Research Institute, Rotorua, New Zealand, 57-67. 
[86] Iqbal J. and Cheema, Z.A. (2008) Purple Nutsedge (Cyperus rotundus L.) Management in Cotton with Combined Application of Sorgaab and S-Metolachlor. Pakistan Journal of Botany, 40, 2383-2391.

[87] Razzaq, A., Cheema, Z.A., Jabran, K., Farooq, M., Khaliq, A., Haider, G. and Basra, S.M.A. (2010) Weed Management in Wheat through Combination of Allelopathic Water Extract with Reduced Doses of Herbicides. Pakistan Journal of Weed Science Research, 16, 247-256.

[88] Dilday, R.H., Frans, R.E., Semidey, N., Smith, R.J. and Oliver, L.R. (1992) Weed Control with Crop Allelopathy. Arkansas Farm Research, 41, 14-15.

[89] Wu, H., Pratley, J., Lemerle, D. and Haig, T. (1999) Crop Cultivars with Allelopathic Capability. Weed Research, 39, 171-180. https://doi.org/10.1046/j.1365-3180.1999.00136.x

[90] Mushtaq, M.N., Cheema, Z.A., Khaliq, A. and Naveed, M.R. (2010) A 75\% Reduction in Herbicide Use through Integration with Sorghum + Sunflower Extracts for Weed Management in Wheat. Journal of the Science of Food and Agriculture, 90, 1897-1904. https://doi.org/10.1002/jsfa.4159

[91] Xuan, T.D., Tsuzuki, E., Uematsu, H. and Terao, H. (2001) Weed Control with Alfalfa Pellets in Transplanting Rice. Weed Biology and Management, 1, 231-235. https://doi.org/10.1046/j.1445-6664.2001.00034.x

[92] Hong, N.H., Xuan, T.D., Eiji, T. and Khanh, T.D. (2004) Paddy Weed Control by Higher Plants from Southeast Asia. Crop Protection, 23, 255-261. https://doi.org/10.1016/j.cropro.2003.08.008

[93] Laosinwattana, C., Huypao, J., Charoenying, P., Lertdetdecha, K. and Teerarak, M. (2013) Herbicidal Activity of PORGANICTM, Application and Its Potential Used as Natural Post-Emergence Herbicide in Paddy Rice. Proceedings of the 24th Asian-Pacific Weed Science Society Conference, 376-382.

[94] Xuan, T.D., Shinkichi, T., Khanh, T.D. and Chung, I.M. (2005) Biological Control of Weeds and Plant Pathogens in Paddy Rice by Exploiting Plant Allelopathy: An Overview. Crop Protection, 24, 197-206. https://doi.org/10.1016/j.cropro.2004.08.004

[95] Einhellig, F.A. and Souza, I.F. (1992). Phytotoxicity of Sorgoleone Found in Grain Sorghum Root Exudates. Journal of Chemical Ecology, 18, 1-11. https://doi.org/10.1007/BF00997160

[96] Nimbal, C.I., Pedersen, J.F., Yerkes, C.N., Weston, L.A. and Weller, S.C. (1996) Phytotoxicity and Distribution of Sorgoleone in Grain Sorghum Germplasm. Journal of Agricultural and Food Chemistry, 44, 1343-1347. https://doi.org/10.1021/jf950561n

[97] Czarnota, M.A., Paul, R.N., Dayan, F.E., Nimbal, C.I. and Weston, L.A. (2001) Mode of Action, Localization of Production, Chemical Nature, and Activity of Sorgoleone: A Potent PSII Inhibitor in Sorghum spp. Root Exudates. Weed Technology, 15, 813-825. https://doi.org/10.1614/0890-037X(2001)015[0813:MOALOP]2.0.CO;2

[98] Weston, L.A. and Czarnota, M.A. (2001) Activity and Persistence of Sorgoleone, a Long-Chain Hydroquinone Produced by Sorghum bicolor. Journal of Crop Production, 4, 363-377. https://doi.org/10.1300/J144v04n02_17

[99] Hoagland, R.E. (2009) Toxicity of Tomatine and Tomatidine on Weeds, Crops and Phyto Pathogenetic Fungi. Allelopathy Journal, 23, 425-436.

[100] Dayan, F.E., Romagni, J.G., Tellez, M.R., Romando, A.M. and Duke, S.O. (1999) 
Managing Weeds with Natural Products. Pesticide Outlook, 10, 185-188.

[101] Xuan, T.D., Elzaawely, A.A., Deba, F., Fukuta, M. and Tawata, S. (2006) Mimosine in Leucaena as a Potent Bio-Herbicide. Agronomy for Sustainable Development, 26, 89-97. https://doi.org/10.1051/agro:2006001

[102] Cornes, D. (2005) Callisto: A Very Successful Maize Herbicide Inspired by Allelochemistry. Proceedings of 4 th World Congress on Allelopathy, Wagga Wagga, NSW, Australia. http://www.regional.org.au/au/allelopathy/2005/2/7/2636_cornesd.htm

[103] Kato-Noguchi, H., Suzuki, M., Noguchi, K., Ohno, O., Suenaga, K. and Laosinwattana, C. (2016) A Potent Phytotoxic Substance in Aglaia odorata Lour. Chemistry and Biodiversity, 13, 549-554. https://doi.org/10.1002/cbdv.201500175

[104] Dayan, F.E., Cantrell, C.L. and Duke, S.O. (2009) Natural Products in Crop Protection. Bioorganic and Medicinal Chemistry, 17, 4022-4034.

https://doi.org/10.1016/j.bmc.2009.01.046

[105] Bayer Crop Science (2011) Material Safety Data Sheet. https://www.cropscience.bayer.com/en

[106] Kato-Noguchi, H., Tanaka, Y., Murakami, T., Yamamura, S. and Fujihara, S. (2002) Isolation and Identification of an Allelopathic Substance from Peel of Citrus junos. Phytochemistry, 61, 849-853. https://doi.org/10.1016/S0031-9422(02)00382-5

[107] Suwitchayanon, P., Pukclai, P., Ohno, O., Suenaga, K. and Kato-Noguchi, H. (2015) Isolation and Identification of an Allelopathic Substance from Hibiscus sabdariffa. Natural Product Communications, 10, 765-766.

[108] Heisey, R.M. (1996) Identification of an Allelopathic Compound from Ailanthus altissima (Simaroubaceae) and Characterization of Its Herbicidal Activity. American Journal of Botany, 83, 192-200. https://doi.org/10.1002/j.1537-2197.1996.tb12697.x

[109] Islam, A.K.M.M., Ohno, O., Suenaga, K. and Kato-Noguchi, H. (2014) Two Novel Phytotoxic Substances from Leucas aspera. Journal of Plant Physiology, 171, 877-883. https://doi.org/10.1016/j.jplph.2014.03.003

[110] Islam, A.K.M.M., Ohno, O., Suenaga, K. and Kato-Noguchi, H. (2014) Suaveolic Acid: A Potent Phytotoxic Substance of Hyptis suaveolens. The Scientific World Journal, 2014, Article ID: 425942. https://doi.org/10.1155/2014/425942

[111] Suzuki, M., Khan, M.S.I., Iwasaki, A., Suenaga, K. and Kato-Noguchi, H. (2017) Allelopathic Potential and an Allelopathic Substance in Mango Leaves. Acta Agriculturae Scandinavica Section B: Soil Plant Science, 67, 37-42. https://doi.org/10.1080/09064710.2016.1215517

[112] Tuyen, P.T., Xuan, T.D., Anh, T.T.T., Van, T.M., Ahmad, A., Elzaawely, A.A. and Khanh, T.D. (2018) Weed Suppressing Potential and Isolation of Potent Plant Growth Inhibitors from Castanea crenata Sieb. et Zucc. Molecules, 23, 345. https://doi.org/10.3390/molecules23020345

[113] Shao, H., Huang, X., Zhang, Y. and Zhang, C. (2013) Main Alkaloids of Peganum harmala L. and Their Different Effects on Dicot and Monocot Crops. Molecules, 18, 2623-2634. https://doi.org/10.3390/molecules18032623

[114] Kato-Noguchi, H., Salam, M.A., Ohno, O. and Suenaga, K. (2014) Nimbolide B and Nimbic Acid B, Phytotoxic Substances in Neem Leaves with Allelopathic Activity. Molecules, 19, 6929-6940. https://doi.org/10.3390/molecules19066929

[115] Charoenying, P., Teerarak, M. and Laosinwattana, C. (2010) An Allelopathic Substance Isolated from Zanthoxylum limonella Alston Fruit. Scientia Horticulturae (Amsterdam), 125, 411-416. https://doi.org/10.1016/j.scienta.2010.04.045 
[116] Teerarak, M., Charoenying, P. and Laosinwattana, C. (2012) Physiological and Cellular Mechanisms of Natural Herbicide Resource from Aglaia odorata Lour. on Bioassay Plants. Acta Physiologiae Plantarum, 34, 1277-1285. https://doi.org/10.1007/s11738-011-0923-5

[117] Kato-Noguchi, H., Hamada, N., Morita, M. and Suenaga, K. (2013) A Novel Allelopathic Substance, 13-Epi-Orthosiphol N, in Orthosiphon stamineus. Journal of Plant Physiology, 170, 1-5. https://doi.org/10.1016/j.jplph.2012.08.007

[118] Kato-Noguchi, H., Nakamura, K., Ohno, O., Suenaga, K. and Okuda, N. (2017) Asparagus Decline: Autotoxicity and Autotoxic Compounds in Asparagus Rhizomes. Journal of Plant Physiology, 213, 23-29. https://doi.org/10.1016/j.jplph.2017.02.011

[119] Kato-Noguchi, H., Nakamura, K. and Okuda, N. (2018) Involvement of an Autotoxic Compound in Asparagus Decline. Journal of Plant Physiology, 224, 49-55. https://doi.org/10.1016/j.jplph.2018.03.005

[120] Van, T.M., Xuan, T., Minh, T. and Quan, N. (2018) Isolation and Purification of Potent Growth Inhibitors from Piper methysticum Root. Molecules, 23, 1907. https://doi.org/10.3390/molecules23081907

[121] Ohno, S., Yokotani, K.T., Kosemura, S., Node, M., Suzuki, T., Amano, M., Yasui, K., Goto, T., Yamamura, S. and Hasegawa, K. (2001) A Species-Selective Allelopathic Substance from Germinating Sunflower (Helianthus annuus L.) Seeds. Phytochemistry, 56, 577-581. https://doi.org/10.1016/S0031-9422(00)00416-7

[122] Ma, R.J., Wang, N.L., Zhu, H., Guo, S.J. and Chen, D.S. (2009) Isolation and Identification of Allelochemicals from Invasive Plant Ipomoea cairica. Allelopathy Journal, 24, 77-84.

[123] Beninger, C.W. and Hall, J.C. (2005) Allelopathic Activity of Luteolin 7-O- $\beta$-Glucuronide Isolated from Chrysanthemum morifolium L. Biochemical Systematics and Ecology, 33, 103-111. https://doi.org/10.1016/j.bse.2004.06.016

[124] Suwitchayanon, P., Suenaga, K., Iwasaki, A. and Kato-Noguchi, H. (2017) Myrislignan, a Growth Inhibitor from the Roots of Citronella Grass. Natural Products Communications, 12, 1077-1078.

[125] Suwitchayanon, P., Ohno, O., Suenaga, K. and Kato-Noguchi, H. (2017) N-Octanoyl Tyramine, a Phytotoxic Compound in the Roots of Cymbopogon nardus. Acta Physiologiae Plantarum, 39, 123. https://doi.org/10.1007/s11738-017-2419-4

[126] Islam, M.S., Iwasaki, A., Suenaga, K. and Kato-Noguchi, H. (2017) 2-Methoxystypandrone, a Potent Phytotoxic Substance in Rumex maritimus L. Theoretical and Experimental Plant Physiology, 29, 195-202. https://doi.org/10.1007/s40626-017-0095-9

[127] Islam, M.S., Iwasaki, A., Suenaga, K. and Kato-Noguchi, H. (2018) Evaluation of Phytotoxic Potential and Identification of Phytotoxic Compounds in Rumex maritimus. Plant Biosystems, 152, 804-809. https://doi.org/10.1080/11263504.2017.1338630

[128] Boonmee, S., Iwasaki, A., Suenaga, K. and Kato-Noguchi, H. (2018) Evaluation of Phytotoxic Activity of Leaf and Stem Extracts and Identification of a Phytotoxic Substance from Caesalpinia mimosoides Lamk. Theoretical and Experimental Plant Physiology, 30, 129-139. https://doi.org/10.1007/s40626-018-0108-3

[129] Kato-Noguchi, H., Takeshita, S., Kimura, F., Ohno, O. and Suenaga, K. (2013) A Novel Substance with Allelopathic Activity in Ginkgo biloba. Journal of Plant Physiology, 170, 1595-1599. https://doi.org/10.1016/j.jplph.2013.07.003 
[130] Kato-Noguchi, H., Le Thi, H., Teruya, T. and Suenaga, K. (2011) Two Potent Allelopathic Substances in Cucumber Plants. Scientia Horticulturae (Amsterdam), 129, 894-897. https://doi.org/10.1016/j.scienta.2011.04.031

[131] Kato-Noguchi, H., Le Thi, H., Sasaki, H. and Suenaga, K. (2012) A Potent Allelopathic Substance in Cucumber Plants and Allelopathy of Cucumber. Acta Physiologiae Plantarum, 34, 2045-2049. https://doi.org/10.1007/s11738-012-0997-8

[132] Piyatida, P., Suenaga, K. and Kato-Noguchi, H. (2010) Allelopathic Potential and Chemical Composition of Rhinacanthus nasutus Extracts. Allelopathy Journal, 26, 207-216.

[133] Kato-Noguchi, H., Pukclai, P., Ohno, O. and Suenaga, K. (2014) Isolation and Identification of a Plant Growth Inhibitor from Tinospora tuberculata Beumee. Acta Physiologiae Plantarum, 36, 1621-1626. https://doi.org/10.1007/s11738-014-1537-5

[134] Piyatida, P., Suenaga, K., Ohno, O. and Kato-Noguchi, H. (2012) Isolation of Allelopathic Substance from Piper sarmentosum Roxb. Allelopathy Journal, 30, 93-102.

[135] Watanabe, Y., Novaes, P., Varela, R.M., Molinillo, J.M.G., Kato-Noguchi, H. and Macías, F.A. (2014) Phytotoxic Potential of Onopordum acanthium L. (Asteraceae). Chemistry and Biodiversity, 11, 1247-1255. https://doi.org/10.1002/cbdv.201400070

[136] Vidal R.A. and Bauman, T.T. (1997) Fate of Allelochemicals in the Soil. Ciência Rural, 27, 351-357. https://doi.org/10.1590/S0103-84781997000200032

[137] Kobayashi, K. (2004) Factors Affecting Phytotoxic Activity of Allelochemicals in Soil. Weed Biology and Management, 4, 1-7. https://doi.org/10.1111/j.1445-6664.2003.00112.x

[138] Inderjit, Weston, L.A. and Duke, S.O. (2005) Challenges, Achievements and Opportunities in Allelopathy Research. Journal of Plant Interaction, 1, 69-81. https://doi.org/10.1080/17429140600622535

[139] Khanh, T.D., Hong, N.H., Xuan, T.D. and Chung, I.M. (2005) Paddy Weed Control by Medicinal and Leguminous Plants from Southeast Asia. Crop Protection, 24, 421-431. https://doi.org/10.1016/j.cropro.2004.09.020

[140] Inderjit and Bhowmik, P.C. (2002) The Importance of Allelochemicals in Weed Invasiveness and the Natural Suppression. In: Inderjit and Mallik, A.U., Eds., Chemical Ecology of Plant. Allelopathy of aquatic and Terrestrial Ecosystems, Birkhauser Verlag AG, Basal, 187-192. 